Отримано: 16 січня 2020 року

Прорецензовано: 23 січня 2020 року

Прийнято до друку: 29 січня 2020 року

e-mail: vira_chorniy@ukr.net

DOI: $10.25264 / 2519-2558-2020-9(77)-257-261$
Chorniy V. Ya. The problems of raising students awareness (motivation) in the process of foreign languages training. Наукові записки Начіонального університету «Острозька академія»: серія «Філологія». Острог: Вид-во НаУОА, 2020. Вип. 9(77). С. 257-261.

Vira Ya. Chorniy,

Ph.D in Pedagogics

Associate Professor of Foreign Languages Department for Natural Sciences

The Faculty of Foreign Languages

Lviv National University named after Ivan Franko

\title{
THE PROBLEMS OF RAISING STUDENTS AWARENESS (MOTIVATION) IN THE PROCESS OF FOREIGN LANGUAGES TRAINING
}

The article highlights the problems of junior university students' motivation to studying foreign languages. These problems are vital and widely discussed by scholars due to implementation of Bologna process. The author offers to understand the motivation as a process that combines individual and situational parameters aiming to transform the subject situation into the relevant motive. The author proves that the leading motive of the students should be awareness of the necessity of foreign language command for the successful professional activity. But students are primarily influenced by the teacher's motivation. Under this framework the levels of the teacher's activity forming is presented together with the framework of the motives study. On the basis of the references survey common classification of the motives is considered as well as techniques that stimulate the process of communication. The examples are taken from foreign and Ukrainian sources on methodology of teaching. These practical examples prove that communication centered training involves all language training skills. The article contains strategies and examples the above strategies. In the conclusion the reasons that determine students' motivation are considered. It is proved that the most effective way of foreign language teaching is an interactive activity of a teacher and a student. Systematic estimation, encouragement and consideration of students' professional interests are key elements in the process.

Key words: awareness, motivation, stimulus, types of motivation, foreign languages studying, methods of foreign languages teaching, students of non-linguistic specialities.

\section{Чорній Віра Ярославівна,}

кандидат педагогічних наук, дочент кафедри іноземних мов для природничих факультетів факультету іноземних мов Львівського начіонального університету імені Івана Франка

\section{ПРОБЛЕМА ПІДВИЩЕННЯ СВІДОМОСТІ СТУДЕНТІВ ДО НАВЧАННЯ (МОТИВАЦІї) У ПРОЦЕСІ ВИКЛАДАННЯ ІНОЗЕМНИХ МОВ}

У статті йдеться мова про важливу роль мотивації у вивченні іноземних мов студентами молодиих курсів немовних спечіальностей, розглядаються головні види мотивачії і стимулів до навчання іноземних мов, а також пов'язані з ними методичні підходи і прийоми. Доводиться необхідність враховувати мотивачію студентів, обумовлену передусім професійним пізнавальним інтересом. Подається розгляд різних видів мотивації, а також ї̈ максимальний вплив на підвищення результативності навчання. На практичних прикладах показано, як на основі комунікативно-орієнтованого навчання іноземній мові як «підмові» спеціальності здійснюється взаємозв'язане аспектне навчання із залученням всіх видів мовленнєвої діяльності. В зв'язку з цим обтрунтовується велика ефективність вироблення продуктивних умінь у студентів на відміну від рецептивних умінь і навичок, а також заохочення до вивчення професійної іноземної мови, як запоруки конкурентноздатності на ринку прачі.

Ключові слова: усвідомлення, мотивація, стимул, види мотивації, вивчення професійної іноземної мови, студенти немовних спеціальностей.

Implementation of the awareness raising or motivational stage at a university requires the correlation of the content of classes in a foreign language, psychology, ethics in terms of focus on the culture of behavior, preparation of students for future professional activities. In addition, it is necessary to form a positive motivation for cognitive activity of students in the process of learning a foreign language since the motive is to inspire the activity and it directs the whole process.

The motivation to study a foreign language at a non-linguistic university has increased significantly as political, social and economic, cultural changes in the country have identified new challenges for professionals, with the prospect of studying abroad, the possibilities of personal communication with colleagues and the reading of special literature issued abroad. Hence, the tendency for contemporary students is the interest in gaining knowledge of a foreign language, since there is an opportunity to study in another country, to work on the Internet, to find the necessary information in foreign sources, to participate in scientific conferences, etc.

Students must clearly understand the need to learn a foreign language, feel the internal need for learning, because "learning without motivation is ineffective" [1, p. 11].

In addition, first-year students need to learn information about professional culture because it determines the effectiveness of their future activities. And for this purpose it is necessary to constantly replenish the vocabulary.

Professionally oriented English currently occupies the leading position in the field of learning foreign languages in connection with integrational processes, which, although slowed down on the background of the complication of the political situation, nevertheless, continue to develop in the new environment. Professional English is widely demanded, but, unfortunately, many students are aware of this fact only at senior courses, when studying the discipline "foreign language" has already finished. Many students have the opportunity to take part in double degree programs, to undergo training in foreign companies. But because of the low level of proficiency in a foreign language, learners are not able to take advantage of this opportunity. Therefore, before starting training it is necessary to investigate the students motives for learning a foreign language. A motive is understood as "a set of external and internal conditions that cause the activity of the subject and determine its direction" [1, p. 162]. 
Motivation is often defined as the psychological quality that leads a person to goal implementation. In domestic psychology study of motivation has long traditions. Modern ideas about motivation come from the concepts of O. Leontyeva, S. Rubinstein, D. Uznadze $[2,3,4]$.

Uznadze distinguishes the concept of motive and purpose. The goal is an advance result that a person represents. The motive is the stimulus for achieving the goal. Rubinstein believes that objects and phenomena of the outside world act not only as objects of knowledge but also as peculiar behavior engines, as winners - certain impulses to action. He admits that the motive replaces one character of behavior to another: less accepted to more accepted - and thus makes it possible to carry out certain activities. Rubinstein considers the problem of how the motives that determine the circumstances change into something stable that characterizes the personality as the basis in motivation.

In pedagogical studies motivation is considered as the most indisputable and studied factor in the success of learning in general and the study of a foreign language in particular. It is the trigger for any activity, whether it is a labor, communication, or cognition. Jacobson defines three types of learning motivation [5]. First, in his opinion, there is a motivation that can be called "negative". Under that type of motivation he understands the student's drive, caused by the perception of certain inconveniences and troubles that may arise if he/she does not learn (accusations from parents, teachers, and fellow students). Such motivation is unlikely to lead to successful results. Secondly, the motivation, which is positive but also related to the motives that are not laid in the educational activity itself. This motivation is in two forms. In one case, it is determined by the recognized personalities of social aspirations, in connection with which learning is considered as a way to realize its purpose in life. A similar instruction in the study, if it is sufficiently developed and occupies a significant place in the student's personality, gives him/her inspiration to overcome difficulties, to reveal patience and diligence. This is the most valuable motivation. However, if in the process of learning this guidance will not be supported by other motivational factors, it will not provide maximum effect. The third form of motivation is determined by the narrow personal motives of the student: the approval of people from his environment, the path to his own well-being, etc. Jacobson states that the process of acquiring knowledge induces itself to study and the student experiences pleasure from the process and the results of cognitive activity, the discovery of a new, the realization of his/her capabilities and abilities [5]. Consequently, the learning motives are in this case with its goals.

There are a number of variables that until now were considered unimportant but, in fact, are involved in the successful study of a foreign language. They relate to the subject and motivation, the desire to learn language, self-confidence, independence, personal variables (the need for achievements, language skills, language strategies). But Gardner and Lambert believe that motivation is a major factor in the implementation of all the variables that influence the process of learning a foreign language. In his view, "language teaching strategies are likely to not work if the individual is not motivated to learn a language" [6]. The problem of motivation is considered by the American scholar on the three sides - from the standpoint of the student, teacher and researcher trying to understand the contribution of each side, in terms of motivation, in the process of learning a foreign language. During the study, he concludes that an important contribution to the motivation process of learning a foreign language is, first of all, the student himself/herself, and secondly - his/her environment, and then - such an important external factor as the teacher. The researcher's contribution to the success of a particular student learning a foreign language is minimal but he is able to understand the link between factors that will help the student and teacher to achieve higher levels of success.

Modern Ukrainian researchers also investigated the problems of students' motivation raise, including in the study of foreign language. For example, Aristova states that the main criteria for motivation forming during foreign languages studying are the presence of cognitive motives and goals, the presence of positive emotions that cause the learning process, the ability and desire to learn, the ability and ability to apply the knowledge gained in practice. Based on a comprehensive consideration of these indicators, the researcher has identified four levels of motivation for learning a foreign language: the level of motivation lack (negative internal motivation of learning, embedded in the educational activities of the subjects of learning); low (negative external motivation of learning that is outside the learning activities of the subjects); medium (positive external motivation for learning that is directly outside the learning activities of the subjects) and high (positive internal motivation for learning, embedded in the learning activities of the subjects) [7].

Shchukin believes that the principle of motivation is based on understanding the motive as encouraging activities related to meeting specific human needs. It is important for the teacher to know the motives underlying students' activities and to be able to maintain a positive motivation for learning at a fairly high level. This can be achieved thanks to the expedient organization of classes, in the process of which the interests of students, their motives of learning (cognitive, professional, etc.) are taken into account as much as possible. It is important to create the students' emotional and positive attitude towards the learning process. And this largely depends on the individual and personal ideas of students, the pedagogical skill and behavior of the teacher in the classroom, the methods and technologies of learning, which he/she uses (collective forms of work, role-playing games, watching videos). An important role is played by intrinsic motivation, when students' activities are directed to study the content of the subject and mastery of this content (cognitive motivation), to use the language for professional purposes (subject and functional motivation), to watch movies, to get acquainted with the sights of culture (entertaining and cultural motivation), the use of language to increase general education (educational motivation), etc.

Consequently, they distinguish external and internal motivations. The internal depends on the internal environment (teacher, training group, circumstances or envirinment). External motivation is proved by the importance of information about the language being taught, its culture and history, the awareness of the importance of language to meet needs. It is important for the teacher to know and understand the needs that students are guided by, and he/she must constantly support the motivation of learning at a high level [8].

According to Galskaya and Geez concept, a linguistic personality is a multilayered set of linguistic abilities, wit, ability to perform speech acts of varying degrees of complexity, actions that identify and characterize the motives and goals that determine a person's development, behavior, and control his or her text producing and, in the end, ultimately determine the hierarchy of understanding and significance in the language of the model world. It means that the process of learning a foreign language should create conditions that provide the student with the opportunity: 
- freely display all mental operations and actions;

- use language tools to meet personal needs;

- overcome so-called language barriers and obstacles.

In addition, researchers insist that learning a foreign language should stimulate students' high personal motivation to speak and learn the language. Free use of language is not a complete assimilation of these language means. It does not mean their quantity but their quality that allow a person to successfully communicate [9].

The system of managing the forming of motivational mechanisms for learning a foreign language will not be effective unless the educational process creates favorable pedagogical conditions for students' creative learning activities, self-realization of their personality. According to Grishkova, "The student's realization of his/her creative opportunities and personal development are possible only under the following psychological and pedagogical conditions:

- creating educational pedagogical situations that encourage students to become aware of their image-self and adequate selfesteem;

- the advantage of dialogue over the monologue in the communication of the teacher with the students;

- forming the situations of success and a positive self-concept of the student;

- "technologicalization" of the process of learning a foreign language;

- changing the position of the teacher in relation to the student [10].

Setting objectives. The issue of education quality management in the organization of the educational process in the discipline of "Professional English" requires the obligatory consideration of motivational mechanisms which are powerful factors that stimulate the process of its learning by students.

Presenting the main information. While analyzing different points of view the author tries to understand the main incentive can encourage the student to work fruitfully on mastering a foreign language. This can be a powerful source of motivation and how to make the external motivation grow into a stable internal one. The answer to this is obvious. It is the mechanism proposed by the Bologna Process. It lies in the fact of practical implementation of a foreign language during the study or prospective potential employment and employment not only abroad. Practical implementation of this is in the fact that the intelligent student will first of all undertake the study of a foreign language not only in the audience but also independently learn the material from the language, knowledge of which, probably, will open to him/her new opportunities for future successful life, maximum creative and personal realization. But the teacher should remember that it is not enough to outline to students the practical purpose of using their knowledge. It is also necessary to constantly support the students desire to learn and improve their knowledge.

If motivation is natural for "Foreign language" learning as the discipline in a linguistic university then, as a rule, in nonlinguistic higher education institutions, in the absence of a real linguistic environment, artificial motivation is urgently needed. The purpose of the teacher is not only and not so much to get the students acquainted with the subject in the first lesson, how much to interest them, to create conditions for intensifying cognitive activity, to arouse the desire for it. To realize and promote this goal the teacher should use the following tools: a) the organization of information and meetings of both senior and graduate students, which is a benchmark of success in the professional field. This can prove that not only professional knowledge but also a high level of language proficiency have enabled them to achieve their goals; b) creating an environment where knowledge of a foreign language is considered prestigious and students would see real opportunities to increase their level of knowledge; c) activation of students' independent work by engaging them in national and international language conferences with the purpose of understanding that the knowledge of the language gives the opportunity to be aware of the latest developments in science, profession and life in general. A very important role is played by the personality of the teacher, his general and professional culture and pedagogical skills at this stage. It is in this case that he is able to formulate the proper goals and motives of learning, set the tone, show the direction of the educational movement, determine the individual approach of educational activity for each student.

The teacher is the main participant in the learning process. He/she organizes and directs it. In the modern methodology, a studentcentered approach has become widespread. Its essence is to maximize the transfer of the learning initiative to the student, which creates partnerships between the teacher and the students during the classes and maximizes the personal potential of students through a special organization of study. But the main role of the teacher is to manage the learning process, master individual learning tasks, etc. The peculiarity of the organizing the process of training in a foreign language is that the learning is not in the mother tongue but in the language being learned, the acquisition of which involves the solution of two problems: mastering the language system and mastering the means of its practical use in various communication situations. Successful decision-making depends essentially on the teacher's professional training and teaching skills.

Teacher professionalism is often also a motivating mechanism for students to learn a foreign language. It requires a high level of knowledge of its discipline, psychological orientation to pedagogical activity, perfect knowledge of pedagogical technologies, the ability to identify and effectively use the abilities and individual characteristics of the student. In addition to the teacher's functions, pedagogical abilities are of great importance for the effectiveness of pedagogical activity. Abilities are the individual characteristics of the teacher, which largely depends on the nature and quality of knowledge, skills, as well as the success of a particular pedagogical activity.

It is necessary to underline the role of the professional and pedagogical qualities of the teacher which help to increase the student's motivation in learning a foreign language, and the availability of which provides optimal opportunities for managing the quality of the educational process. Among them we can distinguish: general and pedagogical erudition, pedagogical thinking, observation, wit and flexibility of thinking, reflection, pedagogical foresight (pedagogical prognosticism).

As it has been mentioned above, the Bologna Process facilitates the emergence of new, additional sources of motivation in learning a foreign language of professional communication. Students have the opportunity to choose the best higher education institutions in Europe and continue their studies in the professional field. Some universities in Ukraine that are aware of the prospects that the Bologna Process opens have switched to teaching general and special subjects in English. This partly solves the problem of further education and employment of students abroad. Lviv National University named after Ivan Franko is among them. In addition, the department of foreign languages offers its students a more advanced study of English through their parallel studies at 
the correspondence course department of the specialty "Translation", since the student is unable to study in two full-time specialties at the same time. Thus, in parallel with his main specialty, he/she receives a bachelor's degree in technical translation. It is clear that this requires high organization of the student himself/herself and dedication of time to master the language material independently. But there are enough examples of successful combination of full-time and part-time students.

The content and technology of teaching a foreign language must meet the current interests and meet the needs of the student, that is, to reproduce the environment closest to real life and for this purpose the foreign language teacher should show greater interest in the specialties of students of the faculties they serve, be knowledgeable in major in relevant industries. It is necessary to constantly keep in touch with the professors of special departments to determine the actual issues of the student's profession. Textbooks are of particular importance for the activation of students' independent cognitive activity, tutorials and audiovisual learning aids. Departments of foreign languages are working on the creation of methodological materials and terminological dictionaries in order to activate students' independent work and increase its efficiency.

The educational system prepares the economists for work not only in the near future but also in a fairly distant future. The detailed conditions and nature of these activities are even difficult to predict today. Therefore, the choice and justification of the content of education, including learning a foreign language, should also perform some predictive function. This means that the teacher of each discipline should orient himself/herself and orient the students not only to its narrowly utilitarian role but also to the prospects of effective use of the acquired knowledge, skills and abilities in future activity, the forming of their ability and internal need for constant self-education, self-education and self-improvement throughout the active working life.

The goals of any education can only be successfully achieved through active self-study and student self-education. It (education) is capable of providing constant growth of professional qualification and self-improvement of a specialist, promotes perfection of his style of activity, encourages creative search. Therefore, the task of "higher school" is to educate a specialist who is able to constantly improve his/her professional skills. Therefore, the task of the teacher is not only to transfer certain information to students but, first of all, to teach them the means of independent action to obtain and comprehend new information, its practical application.

In addition, there is a long-standing problem for many foreign language teachers: the desire and the need to give students everything as soon as possible. But all the time, we forget that we teach not linguists but specialists who are only users of the language. Therefore, it is necessary to clearly set the goals and objectives of a particular course and try to fulfill them, selecting everything that is necessary and methodically appropriate. It is necessary to learn to prioritize and to reject the secondary, to teach students to use the acquired knowledge, to form in them the habit of working independently. It is well-known that the learning material is better learned and the skills of cognitive activity are formed more intensively by students during their independent work. The positive results obtained from its implementation become a powerful motivational factor for further deepening and improvement of knowledge, skills and abilities.

Each student in the group is an individual. He/she has his/her own unique structure of abilities, advantages in choosing certain topics, problems, types of activities. For greater efficiency of independent work in practical classes the teacher uses individual tasks, during which he takes into account the level of preparation of each student and actually conducts individual work with him/her. The teacher, taking into account the individual features of the student's development, provides him/her with a successful promotion in mastering his native language. The individual approach creates a peculiar mechanism of cognitive resonance that significantly enhances the student's foreign language learning motives and adds confidence in his or her abilities. At the same time, since learning a foreign language is an aggregate of equivalent processes, every student should be aware that the qualitative result of his/her work on mastering the language is determined primarily by his or her own efforts and aspirations. Together with the teacher, he/she is responsible for the success and quality of the learning process.

The problem of students' motivation to perform independent work with language materials becomes more and more acute each year, especially in the context of reduced classroom time for learning foreign languages in higher technical education institutions. Indeed, today, their curriculum provides only four hours a week for the first year of study, which is clearly insufficient and cannot provide for the achievement of their study objectives.

Conclusions and prospects for further research. The success of achieving a good command of a foreign language is the need to ensure continuous learning process in Professional English in the institutions of higher education. According to the National Program on the discipline "Professional English" to achieve the level of B2 + it is required 270 hours of classroom and 120 hours of individual work of students [11]. But really the situation is the following: that students learn the language during the first and the second year only and the number of classes is 80 , individual work - 126. Moreover, after studying the course, there is a two-year break and then those who come to gain Master Degree complain that two years out of the language negates all previous efforts of teachers and students themselves. The phenomenon of language is that it does not forgive oblivion. It is impossible to learn the language and then to forget about it and at the right moment of life to "pull" it from the memory bins and communicate qualitatively. Language requires regular training.

So, the challenge is how, if not to improve, at least maintain a decent level of command of the language. How to help a student who wants and is able to study not lose the level that teachers have shaped over the years? How to maintain the incentive and effort spent to reach this level?

If a teacher is unable to increase the amount of classroom time he or she may be obliged to direct students to effective systematic independent work in the field of language training. At the same time, an interesting motivational mechanism is the work with foreign texts in the specialty in scientific and economic journals and monographs, which is necessary for the fulfillment of certain tasks, coursework, speeches at practical and seminar classes, preparation of a scientific article or report at a scientific conference. The concept of students' individual work can be regarded as a specific type of educational cognitive activity. The student independently, under the action of his/her own motives, evaluates the subject of activity, determines the overall purpose and specific tasks, selects the most appropriate means of solving them to achieve the desired result, exercises the necessary self-control. But it should be noted that this type of activity, as an independent activity, causes a lot of difficulties for students.

Therefore, it seems advisable to plan all the time devoted to learning English in professional communication so that students can maintain this level within two years of completing the compulsory language study, and teachers can control it. In the second, 
third and fourth courses of study for those full-time students who intend to pursue graduate and postgraduate studies are advised to introduce a so-called supportive (or correlated) English language course in correspondence. In August and September students aiming to further study English in professional communication will have the opportunity to attend tutorials, where they will receive tutorials from teachers designed for self-study. That requires learning a certain material and mastering new language skills. But the teacher gives the theoretical part and practical advice on self-discipline. During the modular week, in the middle of the semester, students submit completed tests, meet in consultancy regular meeting with the teachers, receive a credit score and receive a new test assignment. During the winter examinations, the procedure is repeated, and so for the next four semesters. So, we are convinced that such a system of combining full-time study with correspondence will be a good motivational element of maintaining students' interest in learning a foreign language, especially for those students who are focused on practically significant results of its use and not only on mastering a certain knowledge.

\section{Лiтература:}

1. Гончаренко С. У. Український педагогічний словник. К.: Либідь, 1997. 376 с.

2. Леонтьев А. Н. Избранные психологические произведения: В 2 т. М.: Педагогика. Т. 2. 1983. 320 с.

3. Рубинштейн С. Л. Основы общей психологии. М.: Учпедгиз, 1946. 704 с.

4. Узнадзе Д. Н. Психологические исследования. М.: Наука, 1966. С. 404-407.

5. Якобсон П. М. Психологические проблемы мотивации в поведении человека. М.: Просвещение. 1969. 317 с.

6. Gardner R. C. Language Learning Motivation: The Student, the Teacher, and the Researcher. Texas Papers in Foreign Language Education. Pp. $2-4$.

7. Арістова Н. О. Формування мотивації вивчення іноземної мови у студентів вищих нелінгвістичних навчальних закладів: Дис... канд. пед.наук: 13.00.04. К., 2009. URL: http://disser.com.ua/content/350944.html.

8. Щукин А. Н. Обучение иностранным языкам: Теория и практика. М.: Филоматис, 2004. С. 161-162.

9. Гальскова Н. Д., Гез Н. И. Теория обучения иностранным языкам: Лингводидактика и методика. М.: Издат. центр “Академия", 2004. С. 151.

10. Гришкова Р. О. Психолого-педагогічні умови особистісно орієнтованого вивчення іноземної мови. Наук. записки КМА. T. 18. K., 2000. C. 35-36.

11. Програма з англійської мови для професійного спілкування / Колектив авторів: Бакаєва Г. Є., Борисенко О. А., Зуєнок I. I. та ін. К.: Ленвіт. 2005. 119 с.

\section{Bibliography (transliterated):}

1. Goncharenko S. U. Ukraïn'kij pedagogichnij slovnik. K.: Libid', 1997. 376 s.

2. Leont'ev A. N. Izbrannye psihologicheskie proizvedenija: V 2 t. M.: Pedagogika. T. 2. 1983. 320 s.

3. Rubinshtejn S. L. Osnovy obwej psihologii. M.: Uchpedgiz, 1946. $704 \mathrm{~s}$.

4. Uznadze D. N. Psihologicheskie issledovanija. M.: Nauka, 1966. S. 404-407.

5. Jakobson P. M. Psihologicheskie problemy motivacii v povedenii cheloveka. M.: Prosvewenie, 1969. $317 \mathrm{~s}$.

6. Gardner R. C. Language Learning Motivation: The Student, the Teacher, and the Researcher. Texas Papers in Foreign Language Education. Pp. 2-4.

7. Aristova N. O. Formuvannja motivaciï vivchennja inozemnoï movi u studentiv viwih nelingvistichnih navchal'nih zakladiv: Dis... kand. ped. nauk: 13.00.04. K., 2009. URL: http://disser.com.ua/content/3590944.html.

8. Wukin A. N. Obuchenie inostrannym jazykam: Teorija i praktika. M.: Filomatis, 2004. S. 161-162.

9. Gal'skova N. D., Gez N. I. Teorija obuchenija inostrannym jazykam: Lingvodidaktika i metodika. M.: Izdat. centr "Akademija", 2004. S. 151.

10. Grishkova R. O. Psihologo-pedagogichni umovi osobistisno orientovanogo vivchennja inozemnoï movi. Nauk. zapiski KMA. T. 18. K., 2000. S. 35-36.

11. Programa $\mathrm{z}$ anglijs'koï movi dlja profesijnogo spilkuvannja. Kolektiv avtoriv: Baka€va G.€., Borisenko O.A., Zu€nok I.I. ta in. K.: Lenvit, 2005. $119 \mathrm{~s}$ 